\title{
Compaction behavior of dry granulated red wall tile paste prepared using raw materials from Rio de Janeiro State
}

\section{(Comportamento de compactação de massa de revestimento poroso base vermelha granulada a seco preparada com matérias-primas do estado do Rio de Janeiro)}

\author{
S. J. G. Sousa, J. N. F. Holanda \\ Grupo de Materiais Cerâmicos, LAMAV-CCT, Universidade Estadual do Norte Fluminense, Av. Alberto Lamego \\ 2000, Campos dos Goytacazes, RJ 28013-602 \\ holanda@uenf.br
}

\begin{abstract}
This work presents the results of a study about on the compaction behavior of a dry granulated red wall tile paste. The ceramic paste was formulated using raw materials of the Rio de Janeiro state. The raw materials were dry-ground and then microgranulated using a mixer of high intensity. The produced powder was characterized regarding X-ray diffraction, chemical composition, granule size analysis and morphology. The moisture content of the granulated powder (moisture mass/dry mass) varied between 0 and $10 \%$. The granulated powder with different moisture contents was submitted to cold compaction process using a uniaxial die-pressing technique with compaction pressure up to $60 \mathrm{MPa}$. The compaction behavior of the wall tile powder was evaluated through compaction response and compaction rate diagrams. The development of the microstructure during compaction process was followed by scanning electron microscopy. The experimental results show that the green density of the tile compacts behaves as a function of moisture content. It was also found that the compaction process is ruled, at the applied pressure range, by two dominant mechanisms including granule rearrangement and plastic deformation. The rate of densification is high initially, but then decreases rapidly for pressures above apparent yield pressure (2.44 - 5.38 MPa). In addition, the better compaction efficiency was found to be influenced by the moisture content.

Keywords: red wall tile, compaction, dry process.
\end{abstract}

\section{Resumo}

Este trabalho apresenta os resultados de um estudo sobre o comportamento de compactação de uma massa de revestimento cerâmico poroso base vermelha granulada pelo processo via seca. A massa cerâmica foi formulada usando matérias-primas do estado do Rio de Janeiro. As matérias-primas foram moídas a seco e em seguida microgranuladas usando um microgranulador de alta intensidade. $O$ pó obtido foi caracterizado em termos de difração de raios $X$, composição química, análise de tamanho de grânulos e morfologia. $O$ conteúdo de umidade do pó granulado (massa de umidade/massa seca) variou entre 0 e 10\%. O pó granulado com diferentes conteúdos de umidade foi submetido a processo de compactação a frio usando a técnica de prensagem uniaxial com pressão de compactação máxima de $60 \mathrm{MPa}$. O comportamento de compactação do pó de revestimento poroso foi avaliado através de diagramas de resposta de compactação e taxa de compactação. A microestrutura dos compactos foi avaliada por microscopia eletrônica de varredura. Os resultados experimentais mostram que a densidade verde dos compactos se comporta como uma função do conteúdo de umidade. Os resultados também mostram que o processo de compactação é governado, na faixa de pressão aplicada, por dois mecanismos dominantes, incluindo rearranjo de grânulos e deformação plástica. A taxa de densificação é inicialmente alta, mas depois diminui rapidamente para pressões acima da pressão de escoamento aparente do pó (2,44 - 5,38 MPa). Além disso, a melhor eficiência de compactação do pó de revestimento poroso estudado é influenciada pelo conteúdo de umidade.

Palavras-chave: revestimento poroso, compactação, via seca.

\section{INTRODUCTION}

Wall tiles are high porosity products used mainly for coverage of interiors and decorative work, which exhibit high dimensional stability and low hidratability [1]. The formulations of wall tiles are primarily constituted of clays, carbonates and quartz, and are considered to be one of the most complex ceramic materials. Each component within the body formulation contributes differently to the end properties. This type of tile is usually produced by wet grinding, forming, fast drying and fast firing at suitable temperatures.

Dry and semidry uniaxial pressing of granulated powders in a die is the most used forming operation in the ceramic industry $[2,3]$. The compaction step in the tile production process usually requires granulated powders with good 
flowability to help the filling of the die cavity, and also the application of suitable pressures. This gives the green tile pieces homogeneous compaction characteristics and suitable physical and mechanical properties. Some reasons in favor of uniaxial pressing are: i) high productivity; ii) easy of automation; iii) low drying shrinkage; iv) high dimensional stability; and v) suitable green microstructure. Many works on the cold compaction behavior of ceramic powders $[2,4]$ have been reported. However, the studied powders generally are spray dried powders.

In this work red wall tile powder prepared by dry granulation process is used $[5,6]$. The dry preparation process is widely used in the tile industry in the manufacture of floor and wall tiles. Nowadays, this process is of high practical interest because it has the following advantages as compared to the wet process (spray-drying) [7]: i) lower energy costs; ii) elimination of costs of deflocculants and additives; iii) lower maintenance costs; and iv) lower environmental impact. In addition, the powders produced by dry process show quite similar technological characteristics to those spray-dried powders [8]. Thus, the compaction behavior of dry-granulated powders is of high interest from academic and technological viewpoints.

This work deals with the compaction behavior of a dry granulated red wall tile powder. The influence of compaction pressure and moisture content are investigated. The efficiency of compaction is determined using compaction response and compaction rate diagrams [9-12]. These diagrams have been widely used in the study of the compaction behavior of powdered materials such as ceramics, metals and pharmaceuticals.

\section{MATERIALS AND METHODS}

Red wall tile paste used in this work is composed of red clay (70wt.\%), calcareous (15wt.\%) and quartz (15wt.\%). Table I gives the chemical composition of the raw materials.

The granulation process of the wall tile paste was

Table I - Chemical composition of the raw materials (wt.\%). [Tabela I - Composição química das matérias-primas (\% em peso).]

\begin{tabular}{cccc}
\hline Compounds & Red clay & Calcareous & Quartz \\
\hline $\mathrm{SiO}_{2}$ & 53.45 & 6.01 & 99.66 \\
$\mathrm{Al}_{2} \mathrm{O}_{3}$ & 22.67 & 0.81 & 0.15 \\
$\mathrm{Fe}_{2} \mathrm{O}_{3}$ & 9.10 & 0.55 & 0.04 \\
$\mathrm{~K}_{2} \mathrm{O}$ & 2.02 & 0.23 & - \\
$\mathrm{Na}_{2} \mathrm{O}$ & 0.57 & 0.15 & - \\
$\mathrm{CaO}$ & 0.40 & 47.26 & - \\
$\mathrm{MgO}$ & 0.83 & 4.91 & - \\
$\mathrm{P}_{2} \mathrm{O}_{5}$ & 0.18 & 0.07 & - \\
$\mathrm{TiO}_{2}$ & 1.17 & 0.06 & 0.01 \\
$\mathrm{MnO}$ & 0.09 & 0.01 & - \\
$\mathrm{LoI}$ & 9.52 & 39.94 & 0.25 \\
\hline
\end{tabular}

LoI = loss on ignition. performed by three distinct operations: grinding, mixing, and agglomeration. The raw materials were dry-ground (< $75 \mu \mathrm{m}$ ) and mixed using a laboratory mill. The sample of the dry-ground powder was homogenized and granulated in a high intensity mixer with moisture content of $14 \%$ (moisture mass/dry mass). After reducing the moisture content to $10 \%$, $7 \%, 3 \%$ and $0 \%$, the granules were kept in a dessicator for $24 \mathrm{~h}$ to homogenize their moisture content. The granulated powder is sieved to eliminate agglomerates larger than 2 $\mathrm{mm}$.

The granule size distribution of the wall tile powder was determined by standard sieving procedure. The morphology and the surface topography of the granules were observed by scanning electron microscopy (SEM). The real density of the powder particles was measured by picnometry.

The compaction experiments were carried out in a hardened steel die with cylindrical cavity and $26.54 \mathrm{~mm}$ diameter using an Instron 5582 universal test machine at a loading rate of $0.5 \mathrm{~mm} / \mathrm{min}$ in the pressure interval up to 60 MPa. The applied force versus punch displacement curve was determined. After compaction, the green densities of the samples were determined. The relative density of the compacts (green density under a given pressure divided by the real density) was also determined. The compaction response diagrams (relative density versus applied pressure) were generated. In addition, the compaction rate diagrams were generated from the compaction response diagrams by taking the first derivative of the curves. The fracture surface of the compacts was observed by SEM, where the accelerating voltage was kept constant at $15 \mathrm{kV}$. Electrical charging was avoided by gold coating the specimens.

\section{RESULTS AND DISCUSSION}

$\mathrm{X}$-ray diffraction pattern of the wall tile paste is shown in Fig. 1. The main crystalline phases observed are kaolinite $\left(\mathrm{Al}_{2} \mathrm{O}_{3 \times} 2 \mathrm{SiO}_{2} \times 2 \mathrm{H}_{2} \mathrm{O}\right)$, calcite $\left(\mathrm{CaCO}_{3}\right)$, dolomite

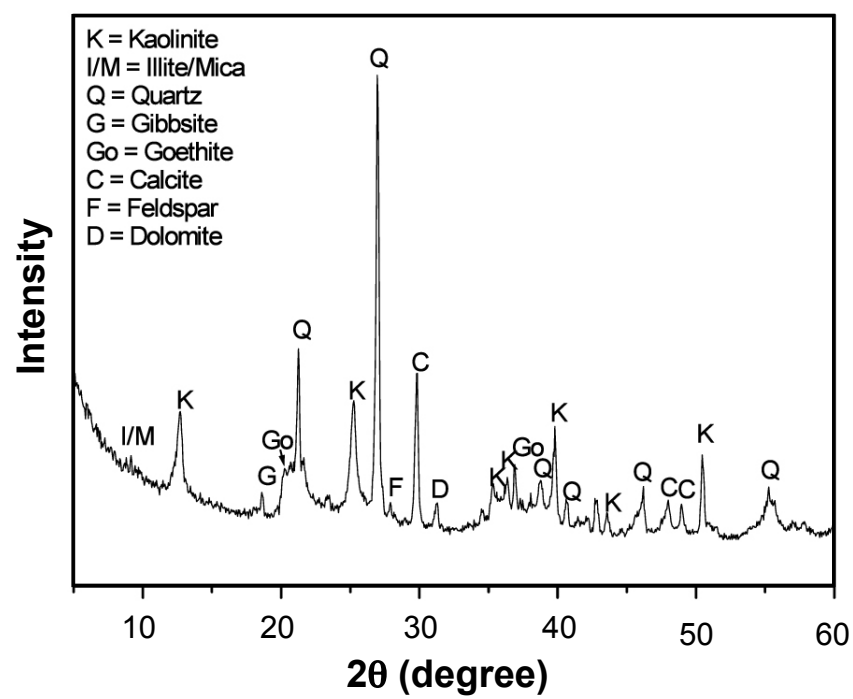

Figure 1: X-ray diffraction pattern of the ceramic paste. [Figura 1: Difratograma de raios X da massa cerâmica.] 
$\left(\mathrm{CaMg}\left(\mathrm{CO}_{3}\right)_{2}\right)$, quartz $\left(\mathrm{SiO}_{2}\right)$, gibbsite $\left(\mathrm{Al}_{2}(\mathrm{OH})_{6}\right)$ and goethite $\left(\alpha-\mathrm{Fe}_{2} \mathrm{O}_{3} \times \mathrm{H}_{2} \mathrm{O}\right)$.

The granule-size distribution of the granulated powder produced by dry process is shown in Fig. 2. The largest fraction of the granulated powder is in the granule-size range of $150-250 \mu \mathrm{m}$. Thus, the red wall tile powder is within the intermediate granule range, which is suitable to obtain good reactivity during firing of the powders produced with the dry process [13]. The low content of granules with size $<150 \mu \mathrm{m}$ indicates that the granulated powder exhibit good flow rate, which is important to automatic die filling during the compaction step. The Fig. 3 shows the morphology and surface features of the dry granulated powder. The nearly spherical shape with rough outside surface is typical of powders produced by mechanical agglomeration of finely dry-ground particles.

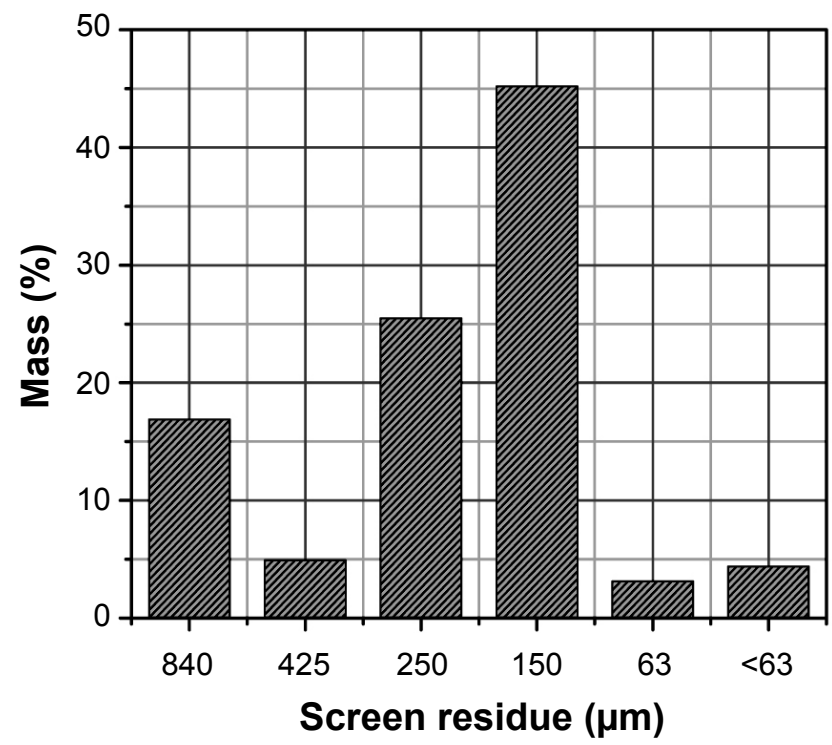

Figure 2: Granule-size distribution of granulated powder produced by the dry process.

[Figura 2: Distribuição de tamanho de grânulos do pó obtido pelo processo via seca.]

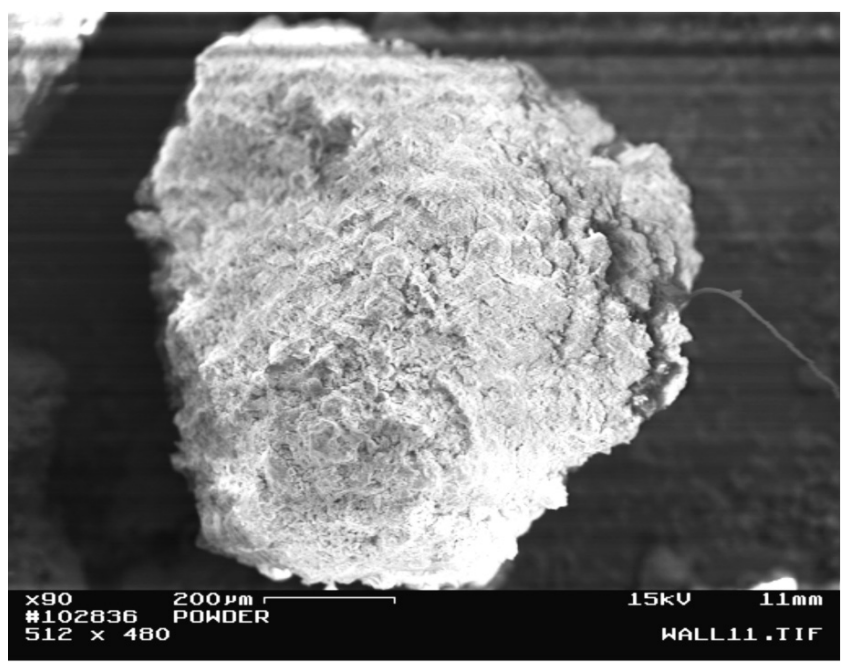

Figure 3: Morphology of the granulated powder.

[Figura 3: Morfologia das partículas do pó granulado.]
Fig. 4 shows the applied force as a function of the punch displacement for different moisture contents. The punch displacement increases with increasing moisture content for a given applied force. The green density as a function of the applied pressure and moisture content is shown in Fig. 5. The green density increases with increasing applied pressure and moisture content, and this is similar to the spray-dried powders behavior $[14,15]$. These results show that a given density can be obtained with several combinations of applied pressure and moisture content. For the studied dry granulated powder, maximum density of $2.04 \mathrm{~g} / \mathrm{cm}^{3}$ was achieved at 60 $\mathrm{MPa}$ and $10 \%$ of moisture. The curves show high convexity above a given applied pressure, which is associated with the sequential action of distinct compaction mechanisms. The

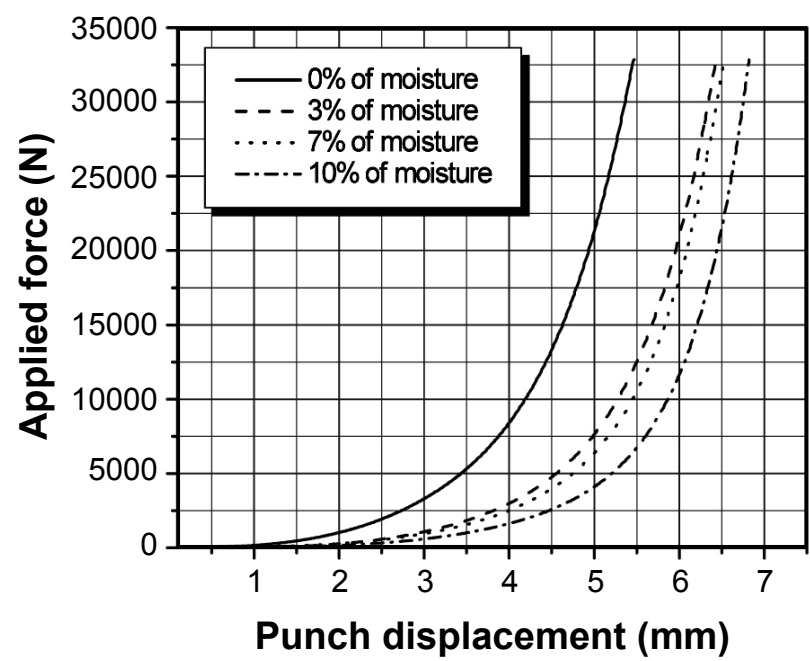

Figure 4: Curves of applied force as a function of the punch displacement.

[Figura 4: Curvas da força aplicada em função do deslocamento do punção.]

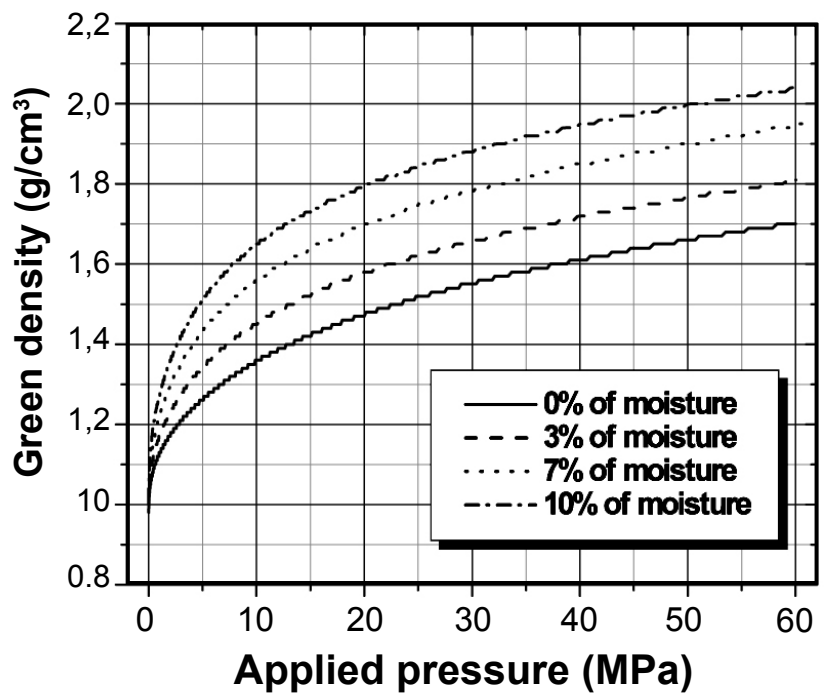

Figure 5: Green density as a function of the compacting pressure. [Figura 5: Massa específica a verde em função da pressão de compactação.] 

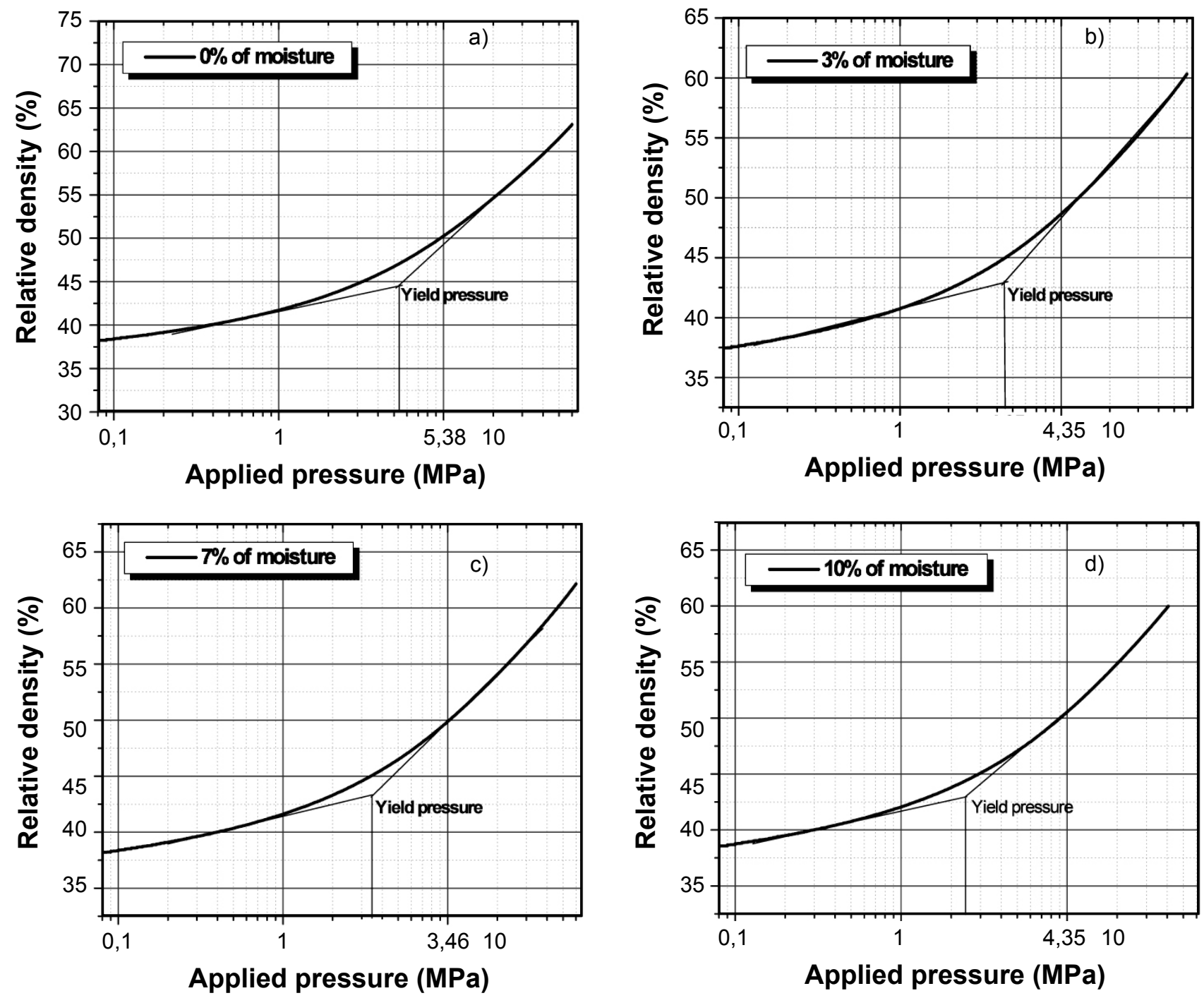

Figure 6: Compaction response diagrams for wall tile paste.

[Figura 6: Diagramas de resposta de compactação para a massa de revestimento poroso.]

effect of the moisture is to increase the densification of the wall tile paste. The moisture acts as a plasticizer of claybased materials, which decreases the friction among the granules and eases the compaction.

Compaction response diagrams for the analyzed wall tile paste with different moisture contents are presented in Fig. 6. It was verified that the integral curves have similar shapes, with two distinct linear compaction regions. However, it can be also observed that there are differences in their particular behavior concerning: i) total relative density and ii) position of inflection points. In general, the total relative density increases with increasing moisture content and applied pressure. The inflection points on the integral curves characterize the change of the mechanism governing compaction in a defined pressure interval [10]. The dry granulated wall tile paste presented values of inflection points in the range of $2.44-5.38 \mathrm{MPa}$, which corresponds to the powder apparent yield pressure. Thus, the apparent yield pressure, as shown in Fig. 7 , is strongly dependent of the

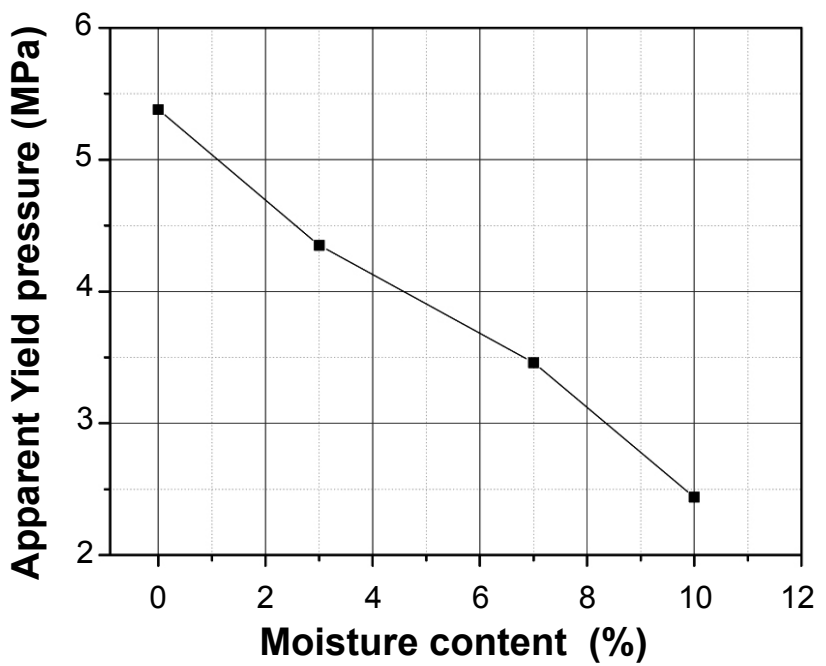

Figure 7: Apparent yield pressure as a function of the moisture content. [Figura 7: Pressão de escoamento em função do conteúdo de umidade.] 
moisture content. The more is the amount of moisture, the lower the apparent yield point is observed. As a consequence, a major densification of the compacts occurred.

The compaction rate diagrams for the wall tile paste are presented in Fig. 8. The rate of densification is high initially, but then decreases rapidly for pressures above the apparent yield pressure. Two compaction regions well-defined in the applied pressure interval can be seen. In the region below the apparent yield pressure, the compact density changes slightly with increasing pressure.

The SEM micrograph of the compact fracture surface after pressing at $3 \mathrm{MPa}$ (Fig. 9) shows that there are considerable intergranular porosity and undeformed

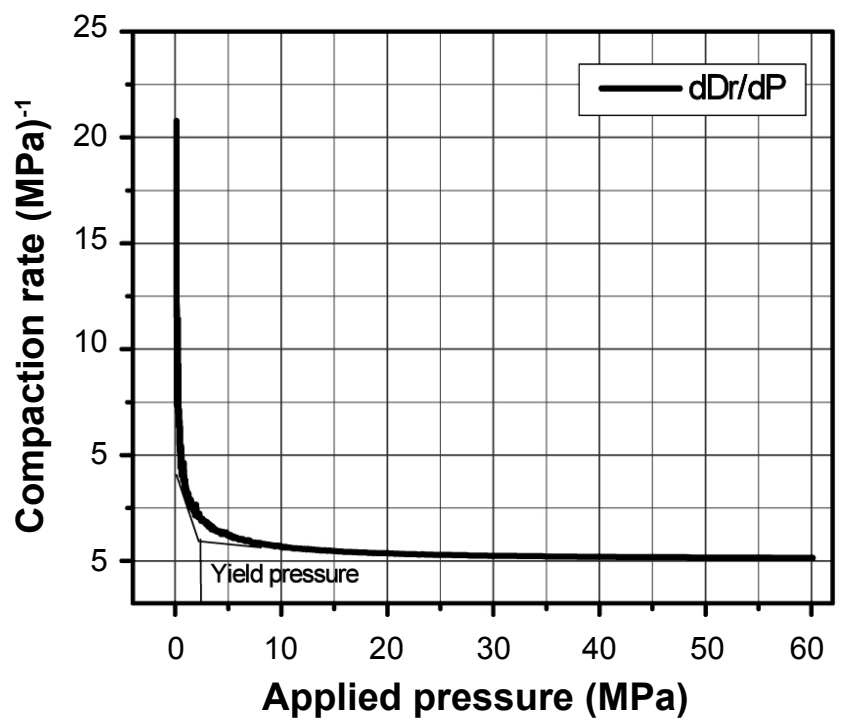

Figure 8: Compaction rate diagram for wall tile paste.

[Figura 8: Diagrama de taxa de compactação para a massa de revestimento poroso.]

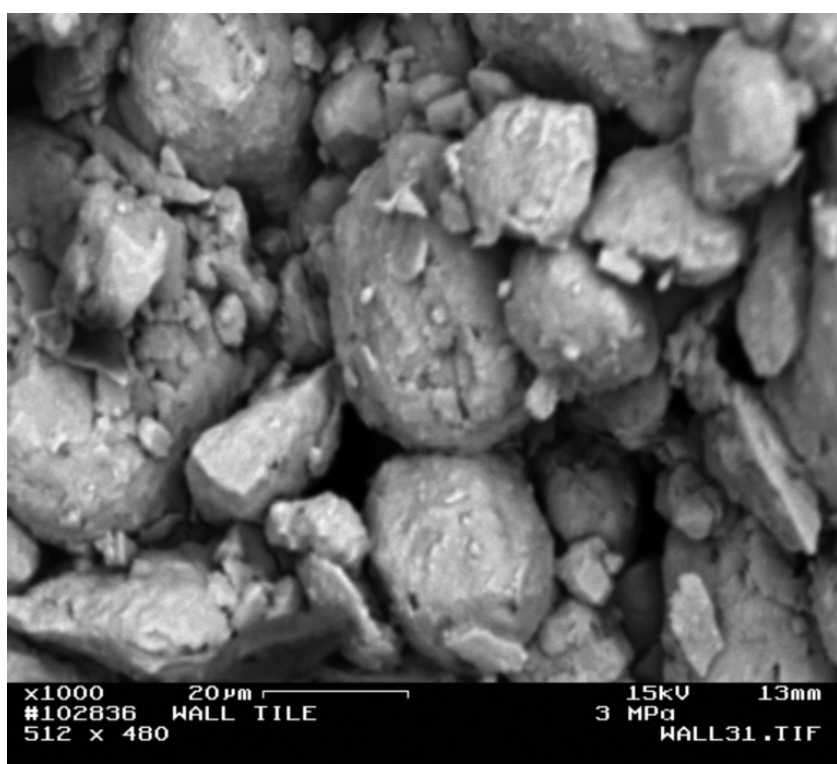

Figure 9: SEM micrograph of the compacted sample at $3 \mathrm{MPa}$.

[Figura 9: Micrografia, por microscopia eletrônica de varredura, da amostra compactada a 3 MPa.]

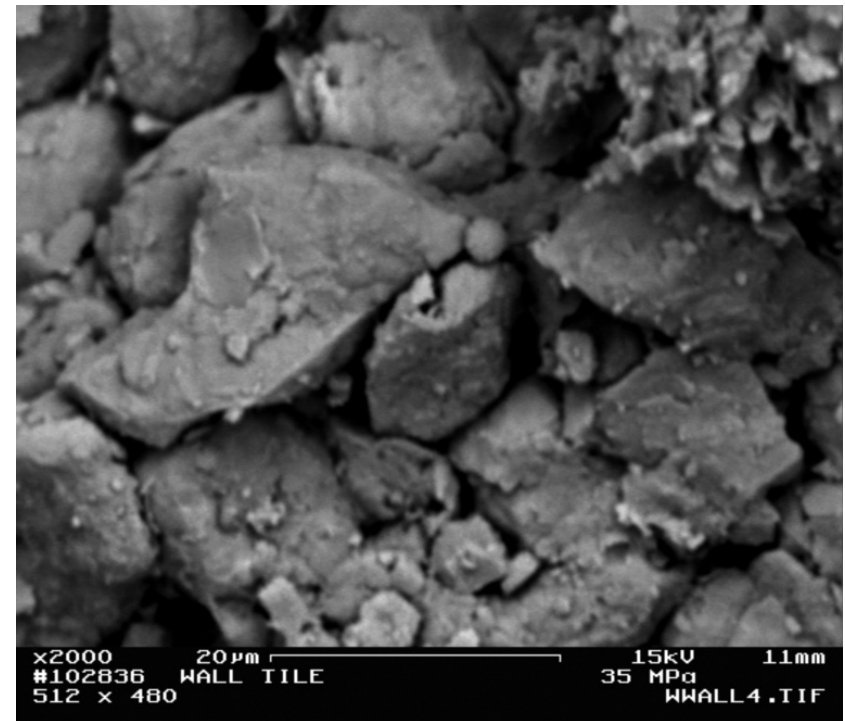

Figure 10: SEM micrograph of the compacted sample at $35 \mathrm{MPa}$. [Figura 10: Micrografia, por microscopia eletrônica de varredura, da amostra compactada a 35 MPa.]

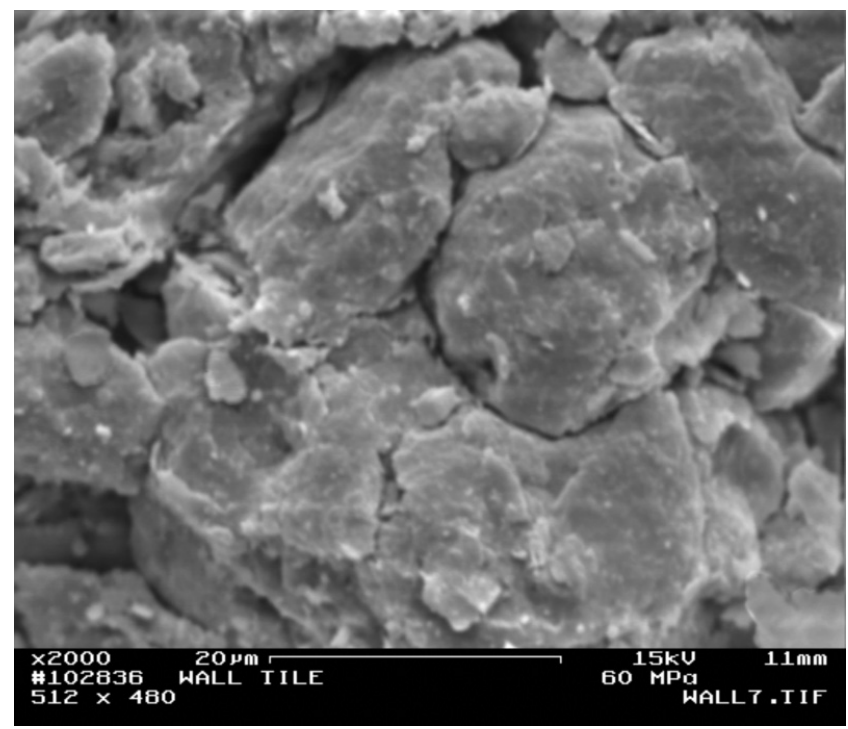

Figure 11: SEM micrograph of the compacted sample at $60 \mathrm{MPa}$. [Figura 11: Micrografia, por microscopia eletrônica de varredura, da amostra compactada a $60 \mathrm{MPa}$.]

granules. Thus, it could be supposed that in this region the dominant compaction mechanism is the granule flow and rearrangement. An increase of applied pressure to 35 $\mathrm{MPa}$ brings about a change in the dominant mechanism. It can be seen in SEM micrograph (Fig. 10), that there are some intergranular pores remaining, but granule deformation occurred. A reduction in the volume and size of the intergranular pores occurred. Thus, the region above the apparent yield pressure is characterized by a mixture of granule rearrangement and plastic deformation mechanisms, being the granule plastic deformation the dominant mechanism. Fig. 11 shows the SEM micrograph of the compact after pressing at $60 \mathrm{MPa}$. It can be seen a structure well densified with high granule deformation. The 
larger pores between deformed granules have practically disappeared.

\section{CONCLUSIONS}

Compaction behavior of red wall tile powder was investigated under cold compaction by employing compaction response and compaction rate diagrams. The compaction behavior of the dry granulated wall tile powder is quite similar to the spray-dried powders. Two compaction regions in the applied pressure interval with distinct dominant compaction mechanisms were identified. For pressures below the apparent yield pressure $(2.44$ - $5.38 \mathrm{MPa}$ ), the granule flow and rearrangement is the dominant mechanism. While for pressures above apparent yield pressure, the dominating mechanism of compaction is a mixture of plastic deformation and rearrangement. It was shown that the increase of moisture content causes a decrease of apparent yield pressure and therefore improves the densification of the wall tile powder in the studied pressure interval. In addition, compacts with same density can be obtained through combination of applied pressure and moisture content.

\section{ACKNOWLEDGMENTS}

The authors would like to thank $\mathrm{CNPq}$ for financial support.

\section{REFERENCES}

[1] A. Escardino, Tile \& Brick Inter. 9, 1 (1999) 14-19.

[2] J. S. Reed, Principles of Ceramic Processing, 2 ed., John Wiley \& Sons, New York, USA (1995).

[3] R. L. K. Matsumoto, Eng. Materials Handbook - Ceramics and Glass, ASM International, New York, USA (1991).

[4] D. M. Liu, C. Fu, Ceram. Inter. 22 (1996) 67-72.

[5] G. Nassetti, Tile \& Brick Inter. 6, 3 (1990) 15-20.

[6] G. Nassetti, Ceram. World Rev. 25 (1997) 82-86.

[7] L. Lolli, Ceram. Acta 11, 5-6 (1999) 5-11.

[8] G. Nassetti, G. Timellini, Ceram. Eng. Sci. Proc. 12, 1-2 (1991) 328-342.

[9] G. L. Messing, C. J. Markhoff, Am. Ceram. Soc. Bull. 61 (1982) 1857-1860.

[10] M. Djuric, R. Marinkovic-Neducin, J. Ranogajec, M. Radeka, Ceram. Int. 21 (1995) 227-230.

[11] M. Radeka, J. Ranogajec, R. Marinkovic-Neducin, B. Zivanovic, Ceram. Int. 21 (1995) 249-255.

[12] B. J. Briscoe, N. Ozkan, Powder Tech. 90 (1997) 195203.

[13] G. Nassetti, C. Palmonari, Ceram. Eng. Sci. Proc. 14, 1-2 (1993) 15-24.

[14] R. A. Youshaw, J. W. Halloraw, Am. Ceram. Soc. Bull. 61, 2 (1982) 227-230.

[15] G. R. Paula, E. Quinteiro, A. O. Boschi, Cerâmica Industrial 2, 3-4 (1997) 28-31.

(Rec. 14/11/2009, Ac. 20/08/2010) 